point of the stress field. In contrast with current understanding (2), there is only one force center until the end of division indicating that the two daughter cells behave in tag-of-war manner to complete furrow abscission. We also investigated the relationship between the stress field asymmetry and the division axis orientation.

In the presentation, we will show these results and discuss the underlying mechanisms.

ref.

1. Burton K and Taylor DL. Nature (1997)

2. Thery M and Bornens M. Current Opinion in Cell Biology (2006)

\section{K1048 細胞性粘菌の運動と形態のダイナミクスるの統計的な解析}

Statistical Analysis of motile and morphological dynamics of Dictyostelium cells

Tatsuo Shibata ${ }^{1,2}$, Akinori Baba ${ }^{1,2}$, Tetsuya Hiraiwa ${ }^{1}$, Naohiro Akuzawa ${ }^{2,3}$ Akihiro Nagamatsu ${ }^{3}$, Masatoshi Nishikawa ${ }^{1,2}\left({ }^{1}\right.$ RIKEN Center for Developmental Biology, ${ }^{2}$ CREST, JST, ${ }^{3}$ Hiroshima University)

Morphological dynamics of cells, such as pseudopodia formation, drives motile behaviors of chemotactic amoebae cells. When there is no external chemotactic cues, cells exhibit spontaneous motility in a random direction. However, their behavior is not a simple random walk, but shows a characteristic persistent random motion with several time constants. Since the cell motility is generated by the extension and contraction of pseudopodia, such complex behaviors could be described by their properties. Under chemoattractant gradient, the extension and contraction processes of pseudopodia are modulated to generate chemotactic motion. To quantitatively describe the morphological and motile processes of Dictyostelium discoideum, we develop a method to analyze the morphological dynamics. We show the results of statistical analysis and quantitative description of the motile and morphological processes.

\section{K1112 原子間力顕微鏡を用いた水平方向の力学刺激による細胞内力ルシウ 厶応答測定}

Measurements of intracellular calcium in response to lateral force by atomic force microscopy

Jumpei Sato, Yusuke Mizutani, Koichi Kawahara, Takaharu Okajima (Grad. Sch. Info. Sci \& Tech, Hokkaido Univ.)

A mechanical stimulus applied to single cell induces the increase in intracellular $\mathrm{Ca}^{2+}$ concentration $\left(\left[\mathrm{Ca}^{2+}\right] \mathrm{i}\right)$, called calcium response, and the change in $\left.\mathrm{Ca}^{2+}\right] \mathrm{i}$, propagates to neighboring cells, which facilitate cell-cell communication. In most previous studies, the effect of normal force applied to cells on the calcium response has been investigated using micropipette technique and atomic force microscopy (AFM), in which cells were locally compressed by the probe. However, it has not been quantitatively understood how lateral force influences the calcium response, which is crucial for elucidating the relation between calcium response and the direction of force. In this study, we measured $\left[\mathrm{Ca}^{2+}\right] \mathrm{i}$ of cells by AFM, in which an oscillating lateral force was applied to cells during indentation with a colloidal-probe cantilever. We found that even in the case of a low normal force, $\left[\mathrm{Ca}^{2+}\right] \mathrm{i}$ of cells was highly induced by applying lateral force. The result indicated that cells were more sensitive to lateral force on the calcium response, compared with normal force. The detail relation between the calcium response and lateral forces depending on the amplitude and frequency of external oscillation will be presented.

\section{K1124＼cjkstart応力緩和測定における細胞シートポアソン比の時間依存性}

Time dependent Poisson's ratio of cell sheets observed in stress relaxation experiments

Masahiro Tsuchiya, Yusuke Mizutani, Koichi Kawahara, Takaharu Okajima (Graduate School of Information Science and Technology, Hokkaido University)

Mechanical properties of living cells are strongly related to their physiological functions. Rheological properties of single cells have been extensively investigated by various microbead techniques, atomic force microscopy and single cell stretching method. These studies revealed that single cells exhibited a power-law behavior in frequency and time domains and the exponent of the relaxation curve was correlated with cytoskeletal structures. Even in these studies, it has not been determined directly the Poisson's ratio of cells, which is one of the most important physical quantities of cells to elucidate cell mechanics. In this study, we measured the time dependent Poisson's ratio during stress relaxation of cell sheet. Cell sheets, which were composed of NIH3T3 or
MDCK cells with a size of ca. $500 \times 400 \mu \mathrm{m}$, were fabricated by peeling off from the microfabricated substrate after the cells formed a confluent monolayer. We found that the Poisson's ratio of cell sheet was increased to $0.25-0.30$ and the curves were well fitted to a single exponential function, while the stress relaxation followed a power-law behavior. Moreover, the disruption of the cytoskeletal structures caused the increase in the power-law exponent and the decrease in the Poisson's ratio. The results implied that the observed timedependent relaxations along the direction parallel and normal to the external loading force was attributed to a non-affine deformation of the complex network structures of cell cytoskeleton.

\section{K1136 多点蛍光相関分光法による生体分子局在变化の時空間相関解析}

Multipoint fluorescence correlation spectroscopy for a spatiotemporal analysis of bio-molecular translocation

Johtaro Yamamoto, Masataka Kinjo (Faculty Adv. Life Sci., Hokkaido Univ.)

Fluorescence correlation spectroscopy (FCS) is a powerful tool by which we can measure bio-molecular dynamics in living cells. Such the dynamics, for example a diffusion coefficient and number of molecules, is one of very important information to estimate and determine cell functions. Measurement points of conventional FCS are however limited to a single point although localization and translocation of the molecules are also important to reveal cell functions.

In this study, we have developed a multipoint FCS system using a holographic illumination realized by a spatial light modulator (SLM). By using this system, dynamics of bio-molecules at multiple points was successfully measured. Each autocorrelation functions obtained from multiple measurement points provides same information as conventional FCS. In addition, cross correlation functions between each measurement points, namely spatio-temporal correlations, provides a molecular distribution and a velocity of a molecular translocation. The multipoint FCS system thus enables us to analyze not only temporal but also spatio-temporal cell functions.

As a demonstration of the multipoint FCS system, we are going to perform a spatio-temporal correlation analysis of glucocorticoid receptors (GR) which translocates to nucleus by addition of dexamethasone. We expect that the multipoint FCS system reveals new aspects of the GR by an analysis of a spatiotemporal response in living cell.

\section{K1148 セミインタクト細胞リシール技術を用いた病㦔モデル細胞構築}

P53 Resealing technique of semi-intact cells: the application to the establishment of disease model cells

Fumi Kano, Yuta Horiuchi, Masayuki Murata (Grad. Sch. of Arts and Sci., Univ. of Tokyo)

Semi-intact cells are cells, whose plasma membranes are permeabilized with detergent or toxins, and are called as "cell-type test tube". We use streptolysin O (SLO) to permeabilize the cell. SLO-mediated pores are about $30 \mathrm{~nm}$ in diameter, which allows the entry of proteins, probes, and small chemical compounds, etc. into cells. Recently, it is found that the SLO-mediated pores can be resealed by calcium ion. We confirmed that the resealed cells restored the endocytosis and exocytosis driven by external stimulus, which are difficult to reconstitute in semi-intact cells due to the permeabilization of plasma membrane, and some resealed cells gained the ability to proliferate. For the application of the resealing cell technique, we have developed the "disease model cells" by adding the disease cytosol, which is prepared from the organs of disease model mice, into semi-intact cells followed by resealing. We found that the endocytosis of transferrin and the signal transduction of specific pathway were delayed in disease model cells containing cytosol from atherosclerosis model mouse. In this study, we will demonstrate the detailed establishment of the disease model cells and will discuss the potentiality and versatility of resealing cell technique.

\section{3:10 16:10 K 会場 /Room K 細胞生物的課題 4}

Cell biology 4

$3 \mathrm{~K} 1322$

磁性細菌表面の分子分解能での高速 AFM イメージング

Live cell surface imaging of magnetic bacteria at molecular resolution by high speed AFM 